\title{
Nitrogen budget and fluxes in Colossoma macropomum ponds
}

\author{
Ricardo Jiménez-Montealegre ${ }^{1}$, Yoram Avnimelech ${ }^{2}$, Johan A J Verreth ${ }^{3} \&$ Marc C J Verdegem ${ }^{3}$ \\ ${ }^{1}$ Escuela de Ciencias Biológicas, Universidad Nacional, Heredia, Costa Rica \\ ${ }^{2}$ The Laboratory for Management of Environmental Systems, Faculty of Agricultural Engineering,Technion, Israel Institute of \\ Technology, Haifa, Israel \\ ${ }^{3}$ Fish Culture and Fisheries Group, Wageningen Institute of Animal Sciences, Wageningen University and Research Center, \\ Wageningen, the Netherlands
}

Correspondence and present address: M C J Verdegem, Centre for Shellfish Research, Netherlands Institute of Fisheries Research, PO Box 77,4400 AB Yerseke, the Netherlands. E-mail: Marc.Verdegem@wur.nl

\begin{abstract}
This study quantified the accumulation of nitrogen (N) in the water column, sediments, fish and seepage water during a production cycle of Colossoma macropomum. By combining estimates of the deposition rates of uneaten feed, faeces and dead phytoplankton with measurements of $\mathrm{N}$ accumulation in the sediment, the rate of decomposition of organic matter in the sediment was estimated. The first-order rate constant for organic matter decomposition was $0.237 \pm 0.019$ day $^{-1}$. Total $\mathrm{N}$ recovery during the first weeks of the experiment was about $65 \%$. Later, the N recovery was close to $100 \%$. The cumulative recovery at the end of the experiment was almost $100 \%$, meaning that the $\mathrm{N}$ budget in the system studied can be fully explained without consideration of $\mathrm{N}$ volatilization, due to either denitrification or ammonia volatilization. In the beginning of the growth cycle, the major flux of $\mathrm{N}$ was sedimentation. Intensive microbial degradation process occurred about 3-4 weeks later, leading to a release of inorganic $\mathrm{N}$ and an approach towards a steady state as to the accumulation of organic N. Feed was irregularly applied during the experiment but fish growth was constant, showing that the fish utilized detrital or planktonic feed during periods of low feeding. Nitrogen accumulated in the pond during periods of excessive feeding and was utilized by the fish during periods of low feeding. This cycling should be further studied and may be an important pond management technique.
\end{abstract}

Keywords: nitrogen budget, nitrogen flux, fishpond

\section{Introduction}

In most aquaculture systems fish retain only 20-30\% of the nitrogen $(\mathrm{N})$ applied as feed (Avnimelech \& Lacher 1979; Boyd 1985; Krom, Porter \& Gordin 1985; Porter, Krom, Robbins, Bricknell \& Davidson 1987; Green \& Boyd 1995). Inorganic N (ammonia $\left(\mathrm{NH}_{3}\right)$ and nitrite $\left(\mathrm{NO}_{3}^{-}\right)$) may be harmful to fish, especially in intensive systems (Hargreaves 1995). Nitrogen not retained by fish is accumulating in the water column, and in the sediments, while smaller fractions are lost with discharged water (drainage, seepage) or lost through volatilization of $\mathrm{NH}_{3}$ and $\mathrm{N}_{2}$ gas. There are reports that $30-95 \%$ of the $\mathrm{N}$ added to the ponds accumulates in the sediment (Avnimelech \& Lacher 1979; Schroeder 1987; Myint, Chiva, Okamoto, Hino \& Wakabayashi 1990; Oláh, Pekar \& Szabo 1994). Several processes affect the accumulation of $\mathrm{N}$ in the sediment, such as sedimentation (Schroeder, Alkon \& Laher 1991), resuspension (Avnimelech \& Wodka 1988; Avnimelech, Kochva \& Hargreaves 1999) and decomposition (Avnimelech 1984), processes that are not well quantified. In previous works (Avnimelech \& Lacher 1979; Boyd 1985; Krom et al. 1985; Porter et al. 1987; Green \& Boyd 1995), N budgets were made by sampling the pond at the start and end of a growth cycle, without giving much attention to these processes. However, pond $\mathrm{N}$ budgets made at different points in time can help quantify some of these processes.

Nitrogen fluxes are related also to feeding strategy. In ponds, nutrients provided through organic wastes stimulate the heterotrophic food chain and depending on fish species, a part of the fish growth is indirectly based on the feed input through the exploitation 
of the heterotrophic food web (Schroeder 1983; Middendorp \& Huisman 1995). Ekanem (1996) fed fish on alternating days. The feed provided also, directly or indirectly, nutrients for the heterotrophic food chain. The fish exploited this food chain also, thereby optimizing the overall food conversion efficiency.

This study quantified the accumulation of $\mathrm{N}$ during a production cycle in feed-driven ponds, both in the water column and in the sediment. In addition, by combining estimates of the deposition rates of uneaten feed, faeces and dead phytoplankton with measurements of $\mathrm{N}$ accumulation in the sediment, the rate of decomposition of organic matter in the sediment was quantified.

Colossoma macropomum, a fast growing species (van der Meer, Machiels \& Verdegem 1995), which is commercially cultured in several South American countries (Goulding \& Carvalho 1982), was used in this study. In ponds, C. macropomum grow best when provided with a nutritionally balanced feed (van der Meer \& Martínez 1993), even when pond-feeding rates are high. The possibility to apply high feeding loads to the ponds while maintaining good growth was considered advantageous for the present study.

\section{Materials and methods}

\section{Feeding and fish management}

Four ponds of $65-\mathrm{m}^{2}$ and 1-m depth were stocked with 30-g C. macropomum at 1 fish $\mathrm{m}^{-2}$. Fish were grown for 111 days. The growing cycle was divided to six periods, about 20 days each. Fish weight was estimated and samples of the sediment and water column were taken at the beginning of the experiment and on days $20,34,55,76,90$ and 111 . At least $60 \%$ of the fish population in each pond was sampled, giving a highly representative population sample.
Fish were fed with a 3-mm dry floating pellets with $35 \%$ crude protein. The feeding levels applied are given in Table 1 . The daily ration was divided into two equal portions applied at 07:00 and 15:00 hours, broadcasted evenly over the pond surface. During the first 3 weeks technical problems caused excessive feed administration of $14.3 \%$ body weight per day. Dissolved oxygen (DO) concentration just above the pond bottom was measured daily at 06:30 hours. Fish were not fed when the early morning DO concentration was $<2 \mathrm{mg} \mathrm{L}^{-1}$. Feeding was resumed when the early morning DO concentration increased to $>5 \mathrm{mgL}^{-1}$. The number of days fish were fed per sampling period is given in Table 1. Fish were not fed on sampling days.

\section{Nitrogen budgets}

A $\mathrm{N}$ budget was prepared for each pond and for each sampling period. Nitrogen inputs considered were feed and in-flowing water. Nitrogen accumulations in fish, water column and sediment as well as $\mathrm{N}$ losses through seepage were quantified.

The protein content on a wet weight basis of fed pond-reared C. macropomum is $15 \%$ (van der Meer \& Martínez 1993). Protein content of fish was assumed to remain constant during the culture period. To estimate the amount of $\mathrm{N}$ storage at stocking and on sampling days in each pond, water and sediment samples were collected from three locations (inlet, outlet and centre) and pooled together. Composited water column samples were filtered through a GF/C Whatman (Whatman International, Kent, UK) glass fibre filter and the filtrate analysed for $\mathrm{NO}_{3}^{-}-\mathrm{N}$ (cadmium reduction), $\mathrm{NO}_{2}^{-}-\mathrm{N}$ (diazotization) and $\mathrm{NH}_{4}^{+}$$\mathrm{N}$ (phenate method) (APHA 1989). Chlorophyll $a$ in non-filtered water column sample was performed using standard methods (APHA 1989). To measure

Table 1 Feeding levels and nitrogen $(\mathrm{N})$ input ( $n=4$ ponds, SD given within parentheses)

\begin{tabular}{|c|c|c|c|c|c|c|}
\hline \multicolumn{2}{|l|}{ Period } & \multicolumn{3}{|l|}{ Feeding } & \multicolumn{2}{|l|}{ Fish } \\
\hline Number & $\begin{array}{l}\text { Time span } \\
\text { (days) }\end{array}$ & Days fed & $\begin{array}{l}\text { Feed per period } \\
\text { (g pond }^{-1} \text { ) }\end{array}$ & $\begin{array}{l}\mathrm{N} \text { input } \\
\left(\mathbf{k g ~ N ~ h a} a^{-1}\right)\end{array}$ & $\begin{array}{l}\text { Specific growth rate } \\
\left(\% \mathrm{BW}_{\text {day }}{ }^{-1}\right)\end{array}$ & $\begin{array}{l}\text { Feed conversion } \\
\text { ratio }\end{array}$ \\
\hline 1 & $1-20(20)$ & $20( \pm 0.0)$ & $9828( \pm 498)$ & $84.7( \pm 4.2)$ & $3.78( \pm 0.22)$ & $5.05( \pm 0.33)$ \\
\hline 2 & $21-34(14)$ & $10( \pm 1.3)$ & $5558( \pm 766)$ & $47.9( \pm 6.6)$ & $4.39( \pm 0.17)$ & $1.90( \pm 0.27)$ \\
\hline 3 & $35-55(21)$ & $7( \pm 1.3)$ & $4447( \pm 802)$ & $38.3( \pm 6.9)$ & $2.33( \pm 0.07)$ & $1.11( \pm 0.21)$ \\
\hline 4 & $56-76(21)$ & $15( \pm 2.8)$ & $15292( \pm 3095)$ & $131.7( \pm 26.7)$ & $2.93( \pm 0.06)$ & $2.13( \pm 0.62)$ \\
\hline 5 & $77-90(14)$ & $6( \pm 1.7)$ & $6573( \pm 2003)$ & $56.6( \pm 17.3)$ & $2.05( \pm 0.05)$ & $1.39( \pm 0.42)$ \\
\hline 6 & $91-111(21)$ & $6( \pm 1.7)$ & $8666( \pm 2469)$ & $74.7( \pm 21.3)$ & $1.89( \pm 0.18)$ & $0.76( \pm 0.14)$ \\
\hline All & $1-111$ & $63( \pm 5.3)$ & $50363( \pm 4231)$ & $433.9( \pm 36.5)$ & $2.89( \pm 0.95)$ & $2.06( \pm 1.48)$ \\
\hline
\end{tabular}


particulate $\mathrm{N}, 500 \mathrm{~mL}$ of sample was filtered through a pre-washed $0.45-\mu \mathrm{m}$ filter and the $\mathrm{N}$ retained on the filter was analysed (Kjeldhal) according to AOAC (1980). Sediment samples were taken using a sampling tube of 6-cm diameter, $15-\mathrm{cm}$ depth. In order to consider the patchy distribution of organic matter in sediments, the three soil samples were analysed for organic matter content (dry ashing, Nelson \& Sommers 1982); the uniformity of ignition loss between samples was used as a criterion permitting composite sampling. Only samples with $<5 \%$ difference in ignition loss were combined. Soil pore water was obtained by centrifugation (4000 rpm; $10 \mathrm{~min}$ ) of the top most 5-cm depth core, and dissolved $\mathrm{N}$ analysed using standard methods (APHA 1989). The remaining soil was dried and the particulate $\mathrm{N}$ was determined after persulphate digestion of the samples (Raveh \& Avnimelech 1979).

Nitrogen losses due to seepage were calculated. A staff gauge was mounted in each pond to measure water level. Water loss was measured daily, and seepage was calculated as

$$
S=L-E+P
$$

where $L$ is the measured water loss, $E$ is the evaporation loss and $P$ is the precipitation. Daily recorded evaporation and precipitation data (in mm per day) from a 100-m away meteorological station were used. Water addition after filling was limited to replacement of losses due to seepage and evaporation. It was assumed that the seepage water had the same $\mathrm{N}$ concentration as the pore water collected from the sediment. The ponds were constructed in a sandy soil and thus had a high hydraulic conductivity and extensive seepage water losses.

\section{Decomposition rate estimation}

The observed accumulation/decrease of organic matter (as N) in the pond sediments was used to estimate the decomposition rates of organic matter based on the following assumptions:

(a) chlorophyll a concentration was converted to phytoplankton $\mathrm{N}$ by assuming a ratio of $5 \mathrm{mg} \mathrm{N} \mathrm{mg}^{-1}$ chlorophyll $a$ (Laws \& Bannister 1980);

(b) $50 \%$ of the phytoplankton biomass deposits daily (Schroeder et al. 1991);

(c) from the feed offered 15\% is not eaten (Boyd \& Tucker 1995);

(d) overall feed digestibility is 70\% (van Dam \& Penning de Vries 1995) and (e) $30 \%$ is excreted as faeces (Porter et al. 1987; Lovell 1988).

The rate of organic $\mathrm{N}$ decomposition was calculated from the changes of total organic $\mathrm{N}$ concentration in the sediment between the initial and final sampling dates. The first order decomposition rate constant $\left(K_{\text {decomp }}\right)$ was obtained through non-linear regression of the equation proposed by Avnimelech, Mozes, Diab and Kochba (1995):

$$
\mathrm{d} S / \mathrm{d} T=B-K(C)
$$

or its integrated form,

$$
\begin{aligned}
S= & B / K_{\text {decomp }}-\left[\left(B-K_{\text {decomp }} \times S_{\mathrm{o}}\right)\right. \\
& \left.\times \mathrm{e}^{-K_{\text {decomp }} \times T}\right] / K_{\text {decomp }}
\end{aligned}
$$

where $S$ is the concentration of organic N, B is the daily addition of component $S, T$ is the time and $S_{\mathrm{o}}$ is the concentration of organic $\mathrm{N}$ at $T=0$.

\section{Statistical analysis}

A Pearson's correlation matrix was calculated for the principal parameters related to feed conversion, $\mathrm{N}$ input, accumulation (fish, sediment, water column) and seepage in the ponds. At each sampling date, the $\mathrm{N}$ input, accumulation and seepage were summed over all previous sampling periods, and are further referred to as pooled periods.

\section{Results and discussion}

The principal flux in feed driven ponds is the feed flux. This was highly variable in this experiment. An excessive application of feed was given during the first period. Later, low oxygen levels limited days of feed application. Details of feed application levels and timing are given in Table 1. The percentage of growing days during which feed was applied for each period varied from $100 \%$ to $29 \%$.

Fish growth, flux of $\mathrm{N}$ to the fish and feed conversion ratio (FCR) for each period are given in Table 1 and fish growth in Fig. 1. In 111 days, the fish grew from 30 to $698 \mathrm{~g}( \pm 48.5$, SD) realizing an average feed conversion ratio of 1.3 for the different culture periods. Fish growth followed a smooth line, regardless of the abruptness of feed application. Growth was not inhibited even in periods when feed was given only $29 \%$ of the time. Overall, daily fish growth rate was $2.9 \%$ body weight (BW), which is excellent compared with other results with the same fish (e.g. 
van der Meer et al. 1995). The fast growth is accompanied with an extensive use of $\mathrm{N}$.

The smooth growth of the fish can be explained by assuming that the fish utilized detrital or planktonic feed during periods of low feeding. According to several works, fish store less than $25 \%$ of the feed protein (Avnimelech \& Lacher 1979; Schroeder, Wohlfarth, Alkon, Halevy \& Krueger 1990; Green \& Boyd 1995). In certain experimental periods protein retention

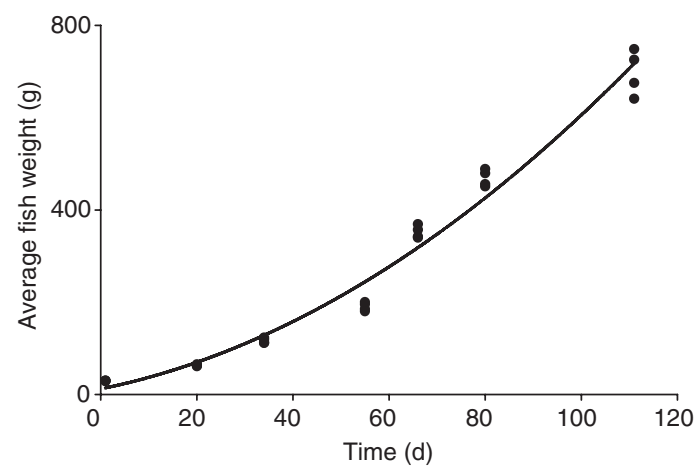

Figure 1 Fish growth of Colossoma macropomum over a 111-day growth period. was lower than the equivalent uptake of $\mathrm{N}$ by the fish (Table 2). The difference between the actual uptake of $\mathrm{N}$ and the potential supply from feed (last column, Table 2) is assumed to represent the protein uptake from the reserves built up in the pond. In period 6 , protein uptake from the pond amounted to more than $50 \%$ of total protein uptake by the fish.

Another major flux is the sedimentation flux. The experimental ponds were hardly used before the present experiment and thus, initially, the sediment had low levels of organic carbon and N (Table 3). Within the first 20 days, the total $\mathrm{N}$ concentrations in the sediment increased by a factor of 50, from about $6 \mathrm{ppm} \mathrm{N}$ to about $250 \mathrm{ppm} \mathrm{N}$. The $\mathrm{N}$ accumulation in the sediment during this period comprised $54 \%$ of the added N (Figs 2 and 3). One possible reason for the very high accumulation is the fact that feeding during the first period was excessive, yet, since even at optimal feeding about $75 \%$ of the $\mathrm{N}$ is not used, similar accumulation should be expected under normal pond operation.

Looking into the composition of the total $\mathrm{N}$ in the sediment (Table 3), during the first period the increased total $\mathrm{N}$ concentration was not followed by

Table 2 Comparison of actual uptake of nitrogen (N) and potential supply from feed (mean $\pm \mathrm{SD}, n=4)$

\begin{tabular}{lllll}
\hline Period & Feed N & $\begin{array}{l}\text { Theoretical feed N } \\
\text { uptake* }\end{array}$ & N retained & $\begin{array}{l}\text { Actual N uptake } \\
\text { from water } \dagger\end{array}$ \\
\hline 1 & $26.66( \pm 1.33)$ & $6.66( \pm 0.33)$ & $2.27( \pm 0.11)$ & $-4.40( \pm 0.35)$ \\
2 & $21.54( \pm 2.97)$ & $5.38( \pm 0.74)$ & $4.90( \pm 0.81)$ & $-4.43( \pm 0.23)$ \\
3 & $11.49( \pm 2.07)$ & $2.87( \pm 0.52)$ & $8.26( \pm 1.74)$ & $-1.56( \pm 0.58)$ \\
4 & $39.50( \pm 8.00)$ & $9.88( \pm 2.00)$ & $8.01( \pm 1.43)$ & $1.65( \pm 2.33)$ \\
5 & $25.47( \pm 7.76)$ & $6.37( \pm 1.94)$ & $12.51( \pm 1.66)$ & $6.91( \pm 0.57)$ \\
6 & $22.39( \pm 6.38)$ & $5.60( \pm 1.59)$ & &
\end{tabular}

All units are expressed as $\mathrm{g} \mathrm{N}$ day ${ }^{-1}$.

$* 25 \%$ of feed $\mathrm{N}$.

$\dagger$ Feed $\mathrm{N}$ uptake - assumed $\mathrm{N}$ from feed. Negative values mean that the fish accumulate less than expected values. Positive values are indicative of fish $\mathrm{N}$ uptake from planktonic or benthic sources.

Table 3 Concentration of organic carbon and nitrogen $(\mathrm{N})$ in sediments and porewater (mean $\pm \mathrm{SD}, n=4)$

\begin{tabular}{|c|c|c|c|c|c|}
\hline \multirow[b]{2}{*}{ Period } & \multicolumn{3}{|l|}{ Sediments } & \multicolumn{2}{|c|}{ Porewater $\left(\mathrm{mg} \mathrm{L}^{-1}\right)$} \\
\hline & $\mathrm{N}-\mathrm{NH}_{4}^{+}\left(\mu \mathrm{g} \mathrm{g}^{-1}\right)$ & Kjeldhal $\mathbf{N}\left(\mu \mathrm{g} \mathrm{g}^{-1}\right)$ & $\begin{array}{l}\text { Organic carbon } \\
\left(\mathrm{mg} \mathrm{g}^{-1}\right)\end{array}$ & $\mathrm{N}-\mathrm{NO}_{3}^{-}$ & $\mathrm{N}-\mathrm{NH}_{4}^{+}$ \\
\hline Initial & $3.27( \pm 0.07)$ & $6.25( \pm 0.94)$ & $0.24( \pm 0.10)$ & $2.67( \pm 0.56)$ & $1.42( \pm 0.47)$ \\
\hline 1 & $2.14( \pm 0.05)$ & $254.51( \pm 15.51)$ & $2.75( \pm 1.79)$ & $3.60( \pm 3.41)$ & $2.29( \pm 2.65)$ \\
\hline 2 & $4.57( \pm 0.11)$ & $389.60( \pm 30.72)$ & $11.27( \pm 0.36)$ & $8.97( \pm 0.94)$ & $7.56( \pm 6.71)$ \\
\hline 3 & $7.13( \pm 0.08)$ & $301.04( \pm 30.42)$ & $6.73( \pm 0.54)$ & $17.99( \pm 3.80)$ & $23.64( \pm 16.00)$ \\
\hline 4 & $4.13( \pm 0.12)$ & $399.52( \pm 12.13)$ & $14.32( \pm 0.48)$ & $19.95( \pm 2.84)$ & $29.98( \pm 11.44)$ \\
\hline 5 & $5.09( \pm 0.06)$ & $137.74( \pm 93.99)$ & $13.70( \pm 0.40)$ & $24.01( \pm 8.77)$ & $57.95( \pm 57.39)$ \\
\hline 6 & $2.10( \pm 0.09)$ & $225.38( \pm 123.89)$ & $16.37( \pm 0.47)$ & $46.91( \pm 2.71)$ & $62.28( \pm 41.98)$ \\
\hline
\end{tabular}




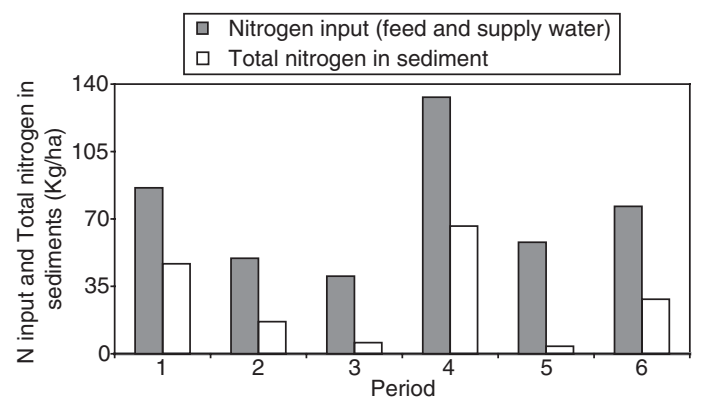

Figure 2 Nitrogen input (as feed and supply water) and total $\mathrm{N}$ accumulation in sediments by period $(n=4)$.

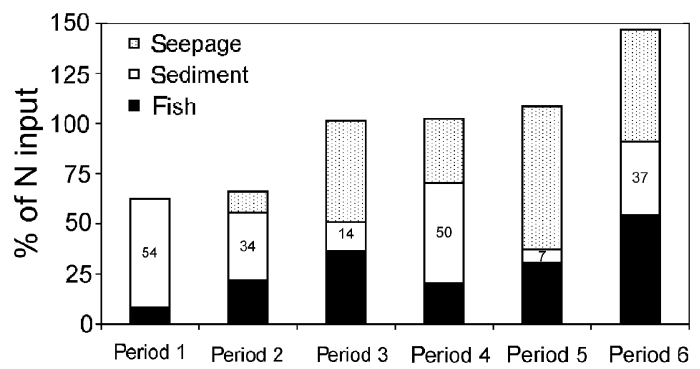

Figure 3 Percentage of nitrogen input found in fish tissue and sediment, and calculated loss through seepage by period. The percentage of $\mathrm{N}$ input found in the sediment is listed by period. Nitrogen accumulated in the water was $<0.15 \%$ and is not shown.

an increase of adsorbed ammonium in the sediment and not by any increase of inorganic $\mathrm{N}$ in the interstitial water. The increase in adsorbed ammonium and of soluble inorganic $\mathrm{N}$ took place only later, reaching a peak at about the end of the third or the fourth periods, i.e. after about 60 days. The increase of organic $\mathrm{N}$ accumulation in the sediment seemed to slow down with time.

The first obvious process to take place was the sedimentation of the residual organic $\mathrm{N}$. The microbial degradation of the sedimented organic $\mathrm{N}$ was very slow in the beginning, thus an insignificant amount of inorganic $\mathrm{N}$ was released. Later, microbial degradation processes were taking place, leading to a build-up of high levels of inorganic $\mathrm{N}$, both adsorbed and soluble. This accelerated decomposition is also reflected in the lowered accumulation of organic $\mathrm{N}$ in the sediment. This trend led to a lower percentage of sedimented $\mathrm{N}$ out of the added one (Figs 3 and 4). A relatively high percentage of accumulation was found in period 4 , but this is probably due to the very high feed input in this period.

It is interesting to note that high nitrate levels were built up in the interstitial water. This is an indication

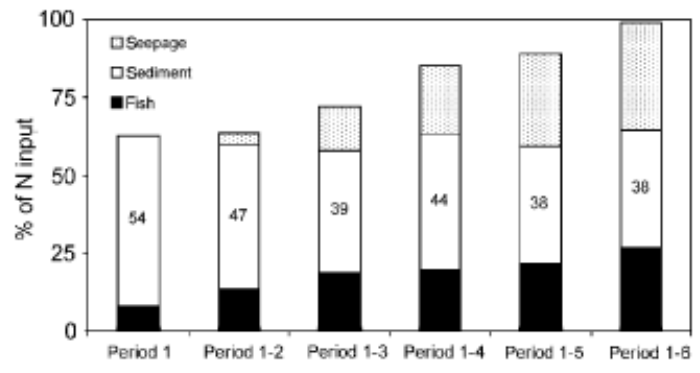

Figure 4 Percentage of nitrogen input found in fish tissue and sediment, and calculated loss through seepage, pooled over time. The percentage of $\mathrm{N}$ input found in the sediment is listed by pooled period. Nitrogen accumulated in the water was $<0.10 \%$ and is not shown.

of aerobic conditions occurring in the sandy sediment in the experimental ponds. It is possible that some inorganic $\mathrm{N}$ diffused from the sediment into the water column, although $\mathrm{N}$ levels in the water remained. The heavy $\mathrm{N}$ loss through seepage (Fig. 3) is a clear implication of the elevated soluble $\mathrm{N}$ in the sediment. Such losses are not typical for ponds having an impermeable bottom and low seepage of water.

An important internal flux is the organic matter and organic $\mathrm{N}$ decomposition fluxes. The decomposition of organic $\mathrm{N}$ was evaluated by comparing the expected accumulation of organic $\mathrm{N}$ with the actual one (Table 4). Organic N sedimentation originated from uneaten feed, faeces and dead plankton. The amounts of these fluxes were calculated based on published results from the literature (Porter et al. 1987; Lovell 1988; Schroeder et al. 1991; Boyd \& Tucker 1995). The difference between the expected sedimentation and the actual one is considered as the amount of decomposed $\mathrm{N}$. The rate of $\mathrm{N}$ decomposition is represented by the first order rate constant, $K$, which was calculated. In the present study, the rate of $\mathrm{N}$ decomposition, as expressed by $K$ was $0.237 \pm 0.019$ $(\mathrm{CV}$ (coefficient of variation) $=8 \%)$. This value is higher than the values given by Avnimelech and colleagues (1995) for the decomposition rate constants in pond bottom sediments, yet, the decomposition processes considered here are taking place in the whole pond, i.e. sediment plus water. In this regard, our results can be compared with those of Avnimelech, Mozes and Weber (1992) who also studied whole system decomposition in tanks and mixed ponds. Their rate constant, 0.06 day $^{-1}$ is also lower than the one found here. The higher decomposition rate constant found in the present study could partly be explained by differences in temperature. It is obvious that sound quantitative data on decomposition of 
Table 4 Estimated deposition rate of organic nitrogen $(\mathrm{N})$ and decomposition rate based on period determinations of organic $\mathrm{N}$ in the sediments of four ponds

\begin{tabular}{|c|c|c|c|c|c|c|}
\hline \multicolumn{4}{|c|}{$\begin{array}{l}\text { Estimated organic } \mathrm{N} \text { deposition rate } \\
\left(\mathrm{mg} \mathrm{N} \mathrm{m}^{-2} \text { day }^{-1}\right)\end{array}$} & \multirow[b]{2}{*}{$\begin{array}{l}\text { Organic } \mathrm{N} \text { accumulation } \\
\text { rate }\left(\mathrm{mg} \mathrm{N} \mathrm{m}^{-2} \text { day }^{-1}\right)\end{array}$} & \multirow[b]{2}{*}{$\begin{array}{l}\text { Decomposition } \\
\text { rate }\left(\mathrm{mg} \mathrm{N} \mathrm{m}^{-2} \text { day }^{-1}\right)\end{array}$} & \multirow[b]{2}{*}{$\begin{array}{l}K_{\text {decomp }} \\
\left(\text { day }^{-1}\right)\end{array}$} \\
\hline Pond & $\begin{array}{l}\text { Uneaten } \\
\text { feed }\end{array}$ & Faeces & $\begin{array}{l}\text { Dead } \\
\text { phytoplankton }\end{array}$ & & & \\
\hline 1 & 60.6 & 20.6 & 49.2 & 4.8 & 125.6 & 0.236 \\
\hline 2 & 64.6 & 22.0 & 54.5 & 2.3 & 138.7 & 0.263 \\
\hline 3 & 55.8 & 19.0 & 53.9 & 6.2 & 122.4 & 0.227 \\
\hline \multirow[t]{2}{*}{4} & 53.6 & 18.2 & 52.5 & 4.1 & 120.2 & 0.219 \\
\hline & & & & Mean \pm SD & $126.7 \pm 8.3$ & $0.237 \pm$ \\
\hline
\end{tabular}

*First-order rate constant for decomposition.

Table 5 Two-tailed Pearson correlation matrix based on six sampling periods and four ponds ( 24 data points)

\begin{tabular}{|c|c|c|c|c|c|}
\hline & $\mathrm{N}$ input & $\begin{array}{l}\text { Fish } \mathrm{N} \\
\text { accumulation }\end{array}$ & $\begin{array}{l}\text { Sediment } \\
\mathrm{N} \text { accumulation }\end{array}$ & $\begin{array}{l}\text { Water column } \\
\mathrm{N} \text { accumulation }\end{array}$ & $\begin{array}{l}\text { Seepage } \\
\mathrm{N} \text { loss }\end{array}$ \\
\hline Feed conversion & 0.3483 & -0.5815 & 0.4808 & 0.5624 & 0.0440 \\
\hline $\mathrm{N}$ input & & 0.3461 & 0.8446 & -0.1786 & -0.4274 \\
\hline Fish $\mathrm{N}$ accumulation & & & 0.1996 & -0.5626 & -0.5688 \\
\hline Sediment $N$ accumulation & & & & 0.1346 & -0.3155 \\
\hline Water column $\mathrm{N}$ accumulation & & & & & 0.3368 \\
\hline
\end{tabular}

Bold values showed significant correlation $(P \leq 0.05)$. All units are expressed as $\mathrm{kg} \mathrm{ha}^{-1}$.

$\mathrm{N}$, nitrogen.

organic matter in fish ponds is lacking. The present data indicate that this process may be quite significant for understanding the pond dynamics.

In Table 5 a correlation matrix is given relating $\mathrm{N}$ input and utilization to $\mathrm{N}$ balance parameters. Feed conversion was positively correlated with $\mathrm{N}$ accumulation in sediment and water column, and inversely correlated with $\mathrm{N}$ accumulation in fish tissue. There was a strong positive correlation between $\mathrm{N}$ input and sediment $\mathrm{N}$ accumulation, and fish $\mathrm{N}$ accumulation was negatively correlated with water column $\mathrm{N}$ accumulation and with seepage $\mathrm{N}$ loss.

The $\mathrm{N}$ budget for each period individually is given in Fig. 3 and the cumulative budget in Fig. 4. Three N fluxes are considered: fish uptake, sedimentation and seepage. Sedimentation was the major flux during the first two periods, followed by a substantial seepage. The total $\mathrm{N}$ recovery during the first two periods was about $65 \%$. Later, along periods $3-5$, the $\mathrm{N}$ recovery was very close to $100 \%(104.0 \pm 3.9)$. The recovery in the last period was almost $150 \%$ (Fig. 3). The cumulative recovery (Fig. 4) is lower than $100 \%$ all along the first five periods, affected by the incomplete recovery during the first two periods. However, the cumulative recovery at the end of the experiment is $100 \%$. These results lead to several interesting conclusions. It seems that the $\mathrm{N}$ budget in the system can be fully explained without any consideration of $\mathrm{N}$ volatilization, due to either denitrification or ammonia volatilization. Gross, Boyd and Wood (1999) found substantial volatilization in catfish ponds in Alabama. However, in the present study ammonium concentrations in the water were low and it seems that the pond bottom was aerated. Possible denitrification in deep sediment layers may have been overlooked in the present study because they were integrated with the seepage losses. The fact that initially $\mathrm{N}$ recovery was incomplete and the fact that a complete recovery was found at the end of the experiment are puzzling. One possible explanation is that $\mathrm{N}$ sedimentation in the first period was patchy and thus the recovery of $\mathrm{N}$ in the sediments was incomplete ( $\mathrm{CV}$ of $\mathrm{N}$ in the sediment was in the order of $5 \%$ normally, but was much higher, $17 \%$, during periods 1 and 2 ). It is possible, yet not proven, that the patches of $\mathrm{N}$ were degraded, colloidal material formed which was more easily uniform distributed over the bottom.

Following other works where $\mathrm{N}$ balance was obtained by comparing the pond in the beginning and at the end of the growth cycle, in this work $\mathrm{N}$ in the pond system was followed along the growing cycle. More information can be obtained through the 
temporal approach. In the beginning of the growth cycle, the major flux of $\mathrm{N}$ was the sedimentation onto the bottom soil. Intensive microbial degradation process took place about 3-4 weeks later, leading to a release of inorganic $\mathrm{N}$ and an approach towards a steady state as to the accumulation of organic $\mathrm{N}$. The whole pond first-order rate constant pertaining to organic $\mathrm{N}$ decomposition was 0.237 day $^{-1}$, a value that is important for pond simulation works.

A complete overall recovery and fairly good temporal recoveries where found as fish $\mathrm{N}$ accumulation, accumulation in the sediment and seepage. The reasons for low recovery of $\mathrm{N}$ during the first few weeks and subsequent $\mathrm{N}$ release should be further studied.

An important scientific and practical conclusion is the storage of protein in the pond system and its subsequent utilization by fish. Nitrogen accumulated in the pond during periods of excessive feeding and was utilized by the fish during periods of low feeding, yielding an overall smooth growth and low FCR. This cycling should be further studied and may be an important pond management technique.

\section{Acknowledgments}

This study was financed by the 'Programa UNALUW/Ciencias Acuáticas', a Cooperation Project between the Escuela de Ciencias Biológicas, Universidad Nacional, Heredia, Costa Rica, and the Fish Culture and Fisheries Group of the Wageningen University and Research Center, the Netherlands. Thanks are given to Magnus van der Meer for his help during the experiment. Prof. Dr E. A. Huisman is also thanked for his valuable comments and suggestions.

\section{References}

AOAC (Association of Official Analytical Chemists) (1980) Official Methods of Analysis. Association of Official Analytical Chemists, Arlington, VA, USA.

APHA (American Public Health Association, American Water Works Association, and Water Pollution Control Federation) (1989) Standard Methods for the Examination of Water and Wastewater, 18th edn. American Public Health Association, New York, USA.

Avnimelech Y. (1984) Reactions in fish pond sediments as inferred from sediment cores data. In: Research on Aquaculture (ed. by H. Rosenthal \& S. Sarig), pp. 41-54. Proceedings of the Second Seminar of the German-Israeli Cooperation in Aquaculture Research, Special Publication No. 8. European Mariculture Society, Bredene, Belgium.

Avnimelech Y. \& Lacher M. (1979) A tentative nutrient balance for intensive fish ponds. Bamidgeh 31, 3-8.
AvnimelechY. \& Wodka M. (1988) Accumulation of nutrients in the sediments of Maaleh Hakishon reclaimed effluents reservoir. Water Research 22, 1437-1442.

AvnimelechY., Mozes N. \& Weber B. (1992) Effects of aeration and mixing on nitrogen and organic matter transformations in simulated fish ponds. Aquacultural Engineering 11, 157-169.

AvnimelechY., Mozes N., Diab S. \& Kochba M. (1995) Rates of organic carbon and nitrogen degradation in intensive fish ponds. Aquaculture 134, 211-216.

AvnimelechY., Kochva M. \& Hargreaves J.A. (1999) Sedimentation and resuspension in earthen fish ponds. Journal of the World Aquaculture Society 30, 401-409.

Boyd C.E. (1985) Chemical budgets for channel catfish ponds. Transactions of the American Fisheries Society 114 , 291-298.

Boyd C.E. \& Tucker C.S. (1995) Sustainability of channel catfish farming. World Aquaculture 26, 45-53.

van Dam A.A. \& Penning de Vries F.W.T. (1995) Parameterization and calibration of a model to simulate effects of feeding level and feed composition on growth of Oreochromis niloticus (L.) and Oncorhynchus mykiss (Walbaum). Aquaculture Research 26, 415-425.

Ekanem S.B. (1996) Effect of feeding frequency, moist and dry feeds on the growth of Chrysichthys nigrodigitatus Lapecede and on pond water quality. Aquaculture Research 27, 107-112.

Goulding M. \& Carvalho M. (1982) Life history and management of the Tambaquí (Colossoma macropomum, Characidae): an important Amazonian food fish. Revista Brasileira de Zoologia 1, 107-133.

Green B.W. \& Boyd C.E. (1995) Chemical budgets for organically fertilized ponds in the dry tropics. Journal of the World Aquaculture Society 26, 284-296.

Gross A., Boyd C.E. \& Wood C.W. (1999) Ammonia volatilization from freshwater fish ponds. Journal of Environmental Quality 28, 793-797.

Hargreaves J.A. (1995) A simulation model of ammonia dynamics in commercial catfish ponds in the southeastern United States. Aquacultural Engineering 16, 27-43.

Krom M.D., Porter C. \& Gordin H. (1985) Nutrient budget of a marine fish pond in Eilat, Israel. Aquaculture 51, 65-80.

Laws E.A. \& Bannister T.T. (1980) Nutrient- and light-limited growth of Thalassiosira fluviatilis in continuous culture, with implications for phytoplankton growth in the ocean. Limnology and Oceanography 25, 457-473.

Lovell T., ed. (1988) Nutrition and Feeding of Fish. Van Nostrand Reinhold, New York, USA.

van der Meer M.B. \& Martínez E. (1993) The effect of fertilization on the growth of pond cultured Colossoma macropomum. In: Actas del Simposio Investigación Acuícola (Acuacultura y Pesca) en Centroamérica (ed. by J. Günther \& K. Kleijn), pp. 53-61. Programa UNA-LUW Acuacultura, Escuela de Ciencias Biológicas, Universidad Nacional, Heredia, Costa Rica. 
van der Meer M.B., Machiels M.A.M. \& Verdegem M.C.J. (1995) The effect of dietary protein level on growth, protein utilization and body composition of Colossoma macropomum. Aquaculture Research 26, 901-909.

Middendorp A.J. \& Huisman E.A. (1995) Pond farming of Nile tilapia, Oreochromis niloticus (L.), in northern Cameroon comparing two different strategies for feeding cottonseed cake in tilapia male monosex culture. Aquaculture Research 26, 731-738.

Myint Z.W., Chiba K., Okamoto K., Hino A. \& Wakabayashi H. (1990) Nitrogen and phosphorous budget aspects of fertilized fish ponds. In: The Second Asian Fisheries Forum (ed. by R. Hirano \& I. Hanyu), pp. 173-176. Asian Fisheries Society, Manila, Philippines.

Nelson D.W. \& Sommers L.E. (1982) Total carbon, organic carbon, and organic matter. In: Methods of Soil Analysis: Part 2, Chemical and Microbiological Properties (ed. by A.L. Page, R.H. Miller \& D.R. Keeney), pp. 539-579. American Society of Agronomy and Soil Science Society of America, Madison, WI, USA.

Oláh J., Pekar F. \& Szabo P. (1994) Nitrogen cycling and retention in fish-cum-livestock ponds. Journal of Applied Ichthyology 10, 341-348.
Porter C., Krom M.D., Robbins M.D., Bricknell M.G. \& Davidson A. (1987) Ammonia excretion and total N budget for filthead seabream (Sparus aurata) and its effect on water quality conditions. Aquaculture 66, 287-289.

Raveh A. \& Avnimelech Y. (1979) Total nitrogen determination in water, soil and plant material. Water Research 13, 911-912.

Schroeder G.L. (1983) The role of natural foods in tilapia growth: a study based on stable isotope analysis. In: Proceedings International Symposium on Tilapia in Aquaculture, Nazareth, Israel, 8-13 May 1983 (ed. by L. Fisherson \& Z.Yaron), pp. 313-322. Tel Aviv University, Tel Aviv, Israel. Schroeder G.L. (1987) Carbon and nitrogen budgets in manured fish ponds on Israel's coastal plain. Aquaculture 62 , 259-279.

Schroeder G.L.,Wohlfarth G., Alkon A., Halevy A. \& Krueger A. (1990) The dominance of algal-based food webs in fish ponds receiving chemical fertilizers plus organic manures. Aquaculture 86, 219-229.

Schroeder G.L., Alkon A. \& Laher M. (1991) Nutrient flow in pond aquaculture systems. In: Aquaculture and Water Quality (ed. by D.E. Brune \& J.R. Tomasso), pp. 498-505. World Aquaculture Society, Baton Rouge, LA, USA. 